\title{
EESTI TEMPERATUURIADJEKTIIVIDE POLÜSEEMIAMALLID
}

\section{Maria Tuulik}

Ülevaade. Artiklis annan ülevaate eesti temperatuuriadjektiivide rühmast ja selgitan seaduspärasusi sõnade semantilises struktuuris. Artiklis kasutatud korpusandmed on pärit "Eesti keele ühendkorpusest 2017”. Korpusanalüüsil kasutan leksikograafilise tarkvara Sketch Engine sõnavisandite, distributiivse tesauruse ja sõnaloendite funktsiooni. Eesmärk on korpuse põhjal tuvastada temperatuuriadjektiivide süstemaatilise polüseemia mallid, mis saaksid pakkuda teoreetilist raamistikku sõnaraamatutööks. Mallide leidmiseks lisan tähendustele semantilised tüübid ja otsin sarnasusi sõnade tähendusvaheldustes. Analüüsiks arendatud semantilised tüübid on kavas lisada Eesti Keele Instituudi uude andmebaasi Ekilex, et võimaldada täpsemat otsingut leksikograafidele ja uurijatele.*

Võtmesõnad: semantilised tüübid, polüseemia, leksikograafia, leksikoloogia, semantika, korpuslingvistika, eesti keel

\section{Sissejuhatus}

Temperatuuri saab eesti keeles leksikaalselt väljendada eri sõnaliikide abil: verbiga (kuumutama, jahutama), substantiiviga (kuumus, palavus), adverbiga (külmalt, soojalt), kuid ilmselt on kõige loomulikum väljendada temperatuuri kui kellegi või millegi omadust adjektiiviga. Ka eesti keele temperatuurisõnade loetelukatses (Sutrop 2004) nimetati valdavalt adjektiive. Samamoodi kui soome keeles (Juvonen, Nikunlassi 2015) võivad paljud eesti temperatuurisõnad siiski esineda nii adjektiivi kui substantiivi rollis (nt soe, külm, kuum, palav).

Artiklis kirjeldan eesti temperatuuriadjektiive ja selgitan seaduspärasusi sõnade semantilises käitumises. Eesmärk on korpuse põhjal tuvastada temperatuuriadjektiivide süstemaatilise polüseemia mallid, mis saaksid pakkuda ka teoreetilist raamistikku sõnaraamatutööks. Töö on esmakordne katse liigitada eesti keele temperatuuriadjektiivide polüseemiamalle. Mallide leidmiseks lisan tähendustele semantilised tüübid ja otsin sarnasusi sõnade tähendusvaheldustes.

* Uurimust on toetanud Eesti Teadusagentuuri grant PSG227 “Eesti keele sõnaliikide kategooriad korpusanalüüsi valguses". 
Adjektiivitähenduste märgendamisel on kasutatud eesti keele (polüseemsete) adjektiivide kirjeldamiseks mõeldud semantilisi tüüpe (Tuulik 2014). Temperatuurisõnade semantikast lähtuvalt olen tüübistikku ka edasi arendanud. Substantiivitähenduste analüüsil on aluseks eesti nimisõnade jaoks väljatöötatud semantilised tüübid (Langemets 2010).

Korpuslingvistikas on juba mõnda aega olnud olulise tähtsusega teemaks korpuste semantiline märgendamine (vt nt Martelli jt 2019). Samuti on tegeletud süstemaatilise polüseemia märgendamisega korpuses ja jõutud järeldusele, et selliste katsetuste edukus varieerub suuresti sõltuvalt aluseks võetud semantilisest tüübistikust (Alonso jt 2013). Seega võib semantilise tüübistiku arendamine ja süstemaatilise polüseemia mallide selgitamine osutuda kasulikuks ka keeletehnoloogiale.

Artiklis kasutatud korpusandmed on pärit "Eesti keele ühendkorpusest 2017" (ENC17), mis sisaldab 1,1 miljardit sõnet. Korpus on loodud Eesti Keele Instituudi ja ettevõtte Lexical Computing Ltd. koostöös. Lingvistilise analüüsi hõlbustamiseks on korpus lemmatiseeritud, märgendatud ja ühestatud analüsaatori EstNLTK abil.

Artiklis kasutatud sõnaraamatuandmed (nt definitsioonide katked tähenduste kirjeldamiseks) on saadud 2019. aastal veebisõnaraamatuna ilmunud "Eesti keele sõnaraamatust" (EKS), mis on Eesti Keele Instituudi keeleportaali Sõnaveeb keskne andmestik (vt Koppel jt 2019). Instituudi tulevikusuund on oma sõnakogusid ühendada ja praegu luuakse sel eesmärgil ühtset struktureeritud andmebaasi Ekilex (vt Tavast jt 2018). Keeleportaal Sõnaveeb on Ekilexi kasutajaliides. EKS-ist on pärit Sõnaveebi esmane märksõnastik (120 ooo sõna), tähendusjaotus, seletused ja kasutusnäited. Sõnaraamatu autorid (Langemets jt 2018) on välja toonud, et uus eesti keele sõnaraamat on korpuspõhine.

\section{Uurimismeetodid}

Temperatuuriadjektiivide semantikat käsitlen artiklis adjektiivikeskselt: tähenduse all on mõeldud adjektiivi leksikaalset tähendust, mis lekseemil on sõnaraamatus (või avaldub korpusteksti kontekstis). Kuigi adjektiivide tähendust üldiselt peetakse abstraktsemaks ja nimisõnast sõltuvaks (vt nt Bhat 1994), on adjektiividel sellegipoolest oma kinnistunud tähenduspiirkonnad, mille keelekasutajad on omaks võtnud.

\subsection{Analüüsi lähtekohad}

Tähenduste täpsustamiseks uurin korpuspäringu programmi Sketch Engine sõnavisandite abil (vt lähemalt Kilgarriff jt 2010, eesti keele kohta Kallas jt 2012) korpusest peamiselt adjektiivi ja substantiivi kollokatsioone, adjektiivi ja verbi kollokatsioone ning visandite $j a / v o \tilde{i}$-suhet, milles avaldub sünonüümiat, kaashüponüümiat ja adjektiivide klassi jaoks eriti olulist suhet antonüümiat.

Tajusõnade uurija Urmas Sutrop (2004) on välja selgitanud, et eesti keele temperatuurisõnad jagunevad põhisõnadeks ja mittepõhisõnadeks. Põhisõnad leiti loetelukatsega, need on külm, soe, kuum ja jahe. Mittepõhisõnadest on sõnadel palav ja leige ka põhisõnade tunnuseid - need kaks sõna moodustavad üleminekurühma. 
Põhitemperatuurisõnad on keeltes enamasti morfoloogiliselt lihtsõnad ja päritolult omasõnad. Teiste domeenide põhisõnad (värvisõnad, maitsesõnad, lõhnasõnad) jagavad sama tendentsi (Sutrop 2002: 39-41). ${ }^{1}$ Kuna põhisõnad on ka korpuse põhjal eesti keele kõige sagedamad temperatuuriadjektiivid, pööran analüüsis neile eraldi tähelepanu.

Temperatuuriadjektiive võtsin valimisse põhimõttel, et sõnal peab esinema vähemalt üks tähendus, mille definitsioonis on temperatuurikomponent eraldi välja toodud. Temperatuurikomponendi all pean silmas eksplitsiitset temperatuurile viitamist temperatuuri põhisõnade (või üleminekurühma sõnade) kaudu, nt arktiline - “(kliima, ilma kohta:) väga külm ja karm; väga külma kliimaga seotud”. Erandina lisasin valimisse ka üksikud sõnad, mille puhul korpuses esines temperatuuritähenduse näited ja vastav tähendus võis ka EKS-is esineda, ent definitsiooni sõnastuses polnud temperatuuri eksplitsiitselt mainitud (nt ahjusoe, troopiline).

Eristan analüüsi huvides esmase temperatuuritähendusega sõnu teistest. Esmase tähenduse all mõtlen sõna kõige sagedamat, primaarset tähendust korpuses (enamasti ka EKS-is esimese tähendusena antud). Kuigi päris kõigil juhtudel ei ole võimalik täieliku kindlusega sõna esmatähendust välja tuua, piisas temperatuuriadjektiivide puhul primaarse tähenduse selgitamiseks kollokatsioonide uurimisest. Esmatähendusega temperatuurisõnad valimis on näiteks külm, palav, jäine ja tulikuum. Teisese temperatuuritähendusega sõnad on näiteks pehme, karm ja mahe. Näiteks sõna pehme esimene tähendus tähistab füüsikalist omadust sõnastikuseletusega “(materjali, aine, asjade kohta:) survele kergesti järele andev; vetruv, painduv", kuid tal esineb ka definitsioon “(ilma, looduse kohta:) suhteliselt soe, mõnusana tunduv (ja vaikne), mitte külm, tuuline ega tormine”, milles sisaldub eksplitsiitselt temperatuurikomponent (märgitud siin kursiiviga), seega on ta temperatuuriadjektiivide valimisse kaasatud.

Süstemaatilise polüseemia kindlakstegemisel lähtun määratlusest, mille Margit Langemets (2010: 31) on Jurij Apresjanile (1974) toetudes kokku võtnud järgmiselt: "Süstemaatilise polüseemia all peetakse silmas olukorda, kus vähemalt kahe sõna mitu tähendust peegeldavad sarnast tähendusstruktuuri."

\subsection{Semantilised tüübid leksikograafias ja korpuses}

Semantiline tüüp on sõnatähenduse analüüsi abstraktne abivahend, mille alusel on võimalik tähendusi rühmitada. Eriti kasulikud on semantilised tüübid polüseemia uurimisel, kuna võimaldavad sarnaseid tähendusi koondada ja leida polüseemiamalle ehk regulaarsusi sõnade tähendusstruktuuride varieerumises. Samuti võib semantilisi tüüpe rakendada sõnastikutöös, et tähendusi rühmitada ja ühtlasemalt kirjeldada. Nimisõnade semantilised tüübid on näiteks TAIM, TOIT, AEG ja ESE (Langemets 2010: 307-318).

Ka polüseemiamallid pakuvad praktilist kasu leksikograafilises töös. Mallid aitavad materjali teadlikumalt organiseerida ja lubavad leksikograafil sama semantilise rühma sõnadele heita laiema, süsteemsema pilgu. Mallide järjepidev esitus sõnaraamatus või andmebaasis ei pruugi olla omaette eesmärk, kuna tähenduste esitamist mõjutavad mitmed tegurid (sihtrühma vajadused, sõna sagedus,

Põhisõnaks määramise metoodikast tajusõnade puhul lähemalt vt nt Uusküla, Sutrop 2011: 47- 62. 
tähenduse sagedus jne), ent mallide tundmine aitab vältida juhuslikumat tähenduse väljajättu. Polüseemsete sõnade korpusanalüüsil on leksikograafi ees korraga palju informatsiooni ning tähenduste jagunemist võib olla keeruline hoomata.

Semantiliste tüüpide teine oluline kasutusvaldkond on korpuste märgendamine loomuliku keele töötlusega tegelevate programmide jaoks. Korpuspäringusüsteemiga Sketch Engine on proovitud luua inglise keele semantilisi sõnavisandeid (McCarthy jt 2015), kasutades märgendamiseks Wordneti (Fellbaum 1998) semantilisi tüüpe nimisõnadele ja verbidele. Tulemuseks näitab sõnavisand tüübipõhist kokkuvõtet, näiteks verbi lendama visandist näeb, kui sageli kuuluvad verbi subjektid semantilistesse tüüpidesse LoOM (ingl ANIMAL, hõlmab ka linde), ESE, AEG jne. Lisaks on võimalik vaadelda subjekti positsiooni võtvaid lemmasid, lendama subjekti tüübi ESE all esinevad sageli nt lennuk, pall, helikopter ja kuul. Semantiliste visandite funktsioon võiks omakorda lihtsustada tähenduste analüüsi leksikograafias. Katses kasutatud Wordneti semantilised tüübid on manuaalselt loodud nagu ka siinse uurimuse tüübid, kuid paljutõotavaid tulemusi on näidanud ka tähenduste automaatne klasterdamine (Martelli jt 2019).

\subsection{Semantilised tüübid temperatuuriadjektiivide analüüsil}

Siiani on EKS-is kasutatud adjektiivide semantiliste tüüpide määramisel kuut laia tüüpi (vt nt Tuulik 2014: 313), mistõttu ei olnud võimalik temperatuuriadjektiive kitsama, temperatuuriga seotud tüübi alusel välja otsida. Valimi kokkupanekuks töötasin läbi EKS-i tüübid oMADUS_FüÜs (mis koondab füüsikalisi omadusi nagu mass, kõrgus, kiirus, heli, värv jne), oMADUs_KVAL (mis koondab hinnangulisi omadusi) ja katustüübi OMADUs. Süstemaatilist polüseemiat aitab aga paremini vaadelda täpsem tüübistik, mida siinses töös täiendasin temperatuuriadjektiivide tähenduste uurimise põhjal. Tüübistiku aluseks on 15 eesti adjektiivide semantilist tüüpi (Tuulik 2014), sealhulgas ka tüüp OMADUS_TEMPERATUUR; lisatud on viis tüüpi, mis osutusid otstarbekaks just temperatuurisõnade analüüsil. Uurimuses selgitatud semantilised tüübid on kavas lisada ka Ekilexi andmebaasi, et võimaldada täpsemat otsingut nii uurijatele kui leksikograafidele.

Kuna temperatuur nähtusena kuulub taju valdkonda ja temperatuurisõnade tähendustes tulevad ilmsiks korduvad vaheldused teiste tajuomadustega, lisandusid tüübistikku semantilised tüübid HäÄL, MAITSE, LÕHN ja PUUDUTUS. Neist HäÄL koondab heli ja häält iseloomustavaid tähendusi, MAITSE maitset iseloomustavaid tähendusi, LÕHN lõhna kirjeldavaid tähendusi ja PUUduTus tähendusi, mis iseloomustavad puudutamisel tekkivat aistingut. Kuigi ka temperatuur ise on seotud kompimismeele ehk puudutamisega, tahtsin analüüsil eristada laiemat temperatuuritähendust ja tähendusi, mis kirjeldavad puudutamisel tekkinud aistingut ja ei pruugi otseselt olla temperatuuritähendused (nt karm kui "(loodusnähtuste, kliimaga seoses:) külm” ja ka kui "puudutamisel mittepehme, kergelt torkiv"). Esialgse 15 tüübi hulka (Tuulik 2014) kuulus meeleelunditega seotud tüüpidest juba VÄRVUS ${ }^{2}$, mis koondab värvitooni ja valgust iseloomustavad tähendusi.

Kõigil valimisse kuuluvatel sõnadel oli vähemalt üks tähendus, mida sai märgistada semantilise tüübiga TEMPERATUUR. Et tähendusvahelduse mustreid uurida,

2 Algses tüübistikus moodustas semantiliste tüüpide nimetuste esiosa täpsustavalt omADUs (nt OMADUS_TEMPERATUUR), kuid kuna artiklis käsitletakse ainult adjektiivide tähendusi, siis on esiosa siin ja edaspidi ära jäetud. 
lisasin polüseemsetele adjektiividele korpuse kollokatsioonide põhjal semantilisi tüüpe. Kui sarnane tähendusvaheldus valimis kordus, siis moodustuski mall. Malli esiosisena on toodud semantiline tüüp TEMPERATUUR nii juhul, kui temperatuuritähendus esines malli kandvatel sõnadel alati esmatähendusena, kui ka juhul, kui temperatuuritähendus esines sõnadel kord esmase, kord teisese tähendusena. Ainus mall, mille nimetuses on TEMPERATUUR teisel kohal, on KOHT-TEMPERATUUR, kuna seda malli kandvatel sõnadel oli temperatuuritähendus eranditult vähem sage ja esmatähendusest tuletatud. Näide 1 demonstreerib sõna arktiline tähendusvaheldust. Kuigi tähendused on selgitatud korpuse abil, kasutan malli näitlikustamiseks peale korpuse kollokatsioonide võimalusel EKS-i definitsioone (või katkeid neist).

(1) arktiline (KOHT-TEMPERATUUR)

- põhjanabalähedane, Arktikasse kuuluv või sealt pärinev. Arktilised jääväljad. (конт)

- (kliima kohta:) väga külm ja karm. Arktilised olud. (TEMPERATUUR)

Korpusele keskendumine on vajalik, et kaasata analüüsi tähendusvaheldusi, mis pole EKS-is esile toodud. Sõnastikes võib kaks (või enam) semantilist tüüpi olla ühe tähenduse alla kokku võetud, nt sõnal mahe on EKS-is üks meeltega seostuv koondtähendus definitsiooniga "meeltele rahulikult mõjuv, meeldivana, mõnusana tajutav, mitte häiriv, mitte liiga ere või vali, (maitselt, lõhnalt) terav või vänge”. Korpuse kollokatsioonide põhjal saaks sõna koondtähenduse asemel aga külge neli erinevat semantilist tüüpi: HÄÄL, vÄRV, MAITSE, LÕHN. Korpuse kõrvale uurin EKS-i, et saada ettekujutust mallide praegusest leksikograafilisest esitusest.

\section{Valim}

Uurimuse temperatuuriadjektiivid on pärit EKS-i algsest andmebaasist Eelex (vt Jürviste jt 2011). Kuna temperatuurisõnad polnud andmebaasis eraldi märgendatud, töötasin läbi rohkem kui 12000 adjektiivi, et leida valimisse sobivaid. Otsisin baasist sõnu, millel vähemalt ühe tähenduse definitsioonis oleks temperatuur tähenduskomponendina eksplitsiitselt välja toodud. Kõigepealt uurisin 3190 leidu, mis olid märgendatud semantilise tüübiga OMADUS_FüÜs, seejärel analüüsisin semantilist tüüpi OMADUS_KVAL (6076 leidu) ja katustüüpi OMADUs (2819 leidu) kandvaid sõnu.

Kokku sobis uurimusse 101 sõna, mis jääb samasse suurusjärku Sutropi (2004) korraldatud temperatuurisõnade loetelukatsega, kus keelejuhid nimetasid kokku 663 sõna, neist 92 erinevat. Siinsest uurimusest jäävad aga kõrvale loetelukatses kõrgele kohale paigutunud adjektiivid kõrge ja madal, mille tähendused eraldiseisvana ei kanna temperatuuri komponenti.

Taju-uurijad on toonud välja meelte hierarhia (2), kus meele olulisus kajastub leksikaalse tähistuse arengus (Viberg 1983).

(2) NÄGEMINE > KUULMINE $>$ PUUDUTAMINE $>$ LÕHN/MAITSE

Kuna EKS-i sõnakogu põhjal on valminud ka värviadjektiivide uurimus (Tuulik, Langemets 2016), on seetôttu hea võimalus kõrvutada puudutuse valdkonda kuuluvate temperatuuriadjektiivide ja nägemisvaldkonda kuuluvate värviadjektiivide rühma. 101 temperatuurile viitava omadussõna kõrval on samas sõnakogus 463 
värvi tähistavat omadussõna - värviadjektiive on sõnastikku jõudnud oluliselt rohkem. Seega võiks eeldada, et neid on ka keeles rohkem. Nii temperatuurisõnad kui värvisõnad on muidugi avatud klassid ja mõlemas rühmas saab näiteks võrdluse alusel hõlpsasti liitadjektiive juurde moodustada, kuid siiski ilmneb sõnavara suuruses rohkem kui neljakordne erinevus. Tähelepanek sobib kokku meelte hierarhia reastusega. Kuna nägemine ja kuulmine on meelte hierarhias puudutamisest eespool, võikski nägemismeelega seotud värvisõnavara olla keeles rikkalikum kui temperatuurisõnavara, mis kuulub kompimismeele, puudutamise valdkonda. Samas mõjutab tõenäoliselt leksikaalset kirjeldusrikkust ka konkreetsete meelte eristusvõime - värve võime ehk enda ümber maailmas tajuda peenemalt ja täpsemalt kui temperatuuriolusid.

Üldiselt koosneb temperatuuriadjektiivide valim üldkeele sõnadest. Seitse adjektiivi on EKS-i baasis märgistatud valdkonnamärgenditega, nt preboreaalne kuulub meteoroloogia ja febriilne meditsiini sõnavarra. EKS-is on kasutusel kaht tüüpi märgendid: registri/stiilimärgendid ja valdkonnamärgendid. Märgend on pandud otstarbe järgi, mitte süstematiseerimiseks, ehk lisatud peaasjalikult siis, kui ilma selleta ei selguks tähenduse kohta kõik vajalik. ${ }^{3}$ Valimisse kuulub ka üks murdemärgendiga adjektiiv: lämmi. Lämmi on läänemeresoome sõna, mis esineb Eestis ainult Lõuna-Eesti murretes (ALFE 2004: 182).

Kõige suurema sagedusega temperatuuriadjektiivid, mille esmatähenduseks on temperatuur, on ühendkorpuse põhjal järgmised: soe (171 300), külm (126 509), kuum (74 584), jahe (28 423), palav (17 905), tuline (16 828), jäine (6886) ja leige (5097). Esimesena tulevadki esile temperatuuri põhisõnad (soe, külm, kuum, jahe); lisaks põhisõnadele ja üleminekurühmale (palav, leige) leiab sagedamate hulgast sõnad tuline ja jäine, mis on ühtlasi valimi kõige suurema sagedusega tuletised. Loendi lõpuosa moodustavad madalaima korpussagedusega suitsusoe (1) ja leitsene (1) ning sügisrõske, mida ühendkorpuses ei esinenudki. Murdetekstid on aga korpuses esindatud ja lämmi asetses 207 esinemiskorraga valimi keskel 51. kohal. Üldse oli korpussageduse põhjal üle 1000 kasutuskorra 33 temperatuuriadjektiivil, ülejäänud 68 sõna kasutus jäi alla tuhande. Temperatuurirühma eesotsas on väiksem hulk sagedaid sõnu (valdavalt juuradjektiivid ja tuletised), ülejäänud rühma moodustavad väiksema sagedusega liitsõnad.

Suurima morfoloogilise rühmana moodustavad liitsõnad poole kogu valimist. Kuna paljud temperatuurisõnad põhinevad võrdlusel, on selline jaotus ootuspärane. Osa valimi liitadjektiividest on moodustatud teise adjektiivi põhjal (nt kärekülm, kibekülm, kõlekülm, krõbekülm), aga enamik sisaldab nimisõnalist võrdlusalust. Sooja puhul esinesid võrdlusalustena ahi, tuba, ihu, keha, käsi, päev, päike, suvi, lüps, trükk, suits ja uni; külma puhul kivi, teras, raud, sügis, õu, jää ja kaev. Kuumaga seoti sõnu kõrb, põrgu ja tuli ning kordusid ka sooja juures esinenud võrdlusalused suvi, ahi ja päike. Sõnast leige moodustatud võrdlusadjektiive oli valimis üks: toaleige. Mitme temperatuuriga seotud liitsõna puhul (nt teraskülm, raudkülm, põrgukuum) on nimisõnaline esiosis aga pigem intensiivistava tähendusega kui sisuliselt võrdlev.

Semantika põhjal jagunes valim sooja ja külma tähistavate sõnade vahel üsna võrdselt, pisut rohkem oli soojale viitavaid sõnu. Kõrget temperatuuri iseloomustavaid või sellega seotud adjektiive (nt palav, päikesesoe, kõrbekuum) oli 53 ja 
madalale temperatuurile viitavaid adjektiive (nt teraskülm, kärekülm, jääkülm, kõhe) 48. Kõrge temperatuuri poolele paigutasin ka leige, mille tähendus "ainult pisut soe" viitab siiski pigem kõrgele kui madalale temperatuurile. Valimi sooja-ja külmasõnade jaotus näitab, et eesti keele sõnavaras on võrdselt võimalusi nii kõrge kui madala temperatuuri iseloomustamiseks. Ka meie kliimas varieerub välitemperatuur ju suurel määral ja aastaaegade seas on olemas nii suvi kui talv.

\section{Polüseemiamallid}

Tutvustan peatükis eesti temperatuuriadjektiivide analüüsil selgunud polüseemiamalle. Iga malli juures toon korpusnäiteid (enamasti Sketch Engine’i sõnavisanditest valitud adjektiivi ja substantiivi kollokatsioone), mis toetavad analüüsi ja selgitavad tähendusvaheldust. Levinumate mallide puhul arutlen ka nende leksikograafilise esituse ja võimaliku motivatsiooni üle. Peatüki lõpus on esitatud polüseemiamallide ülevaatlik tabel.

\subsection{TEMPERATUUR-PSÜHH}

Semantiline tüüp PSÜHH koondab meeleolu, iseloomu ja vaimsete võimetega seotud omadusi. Tüübiga PsüHH saab märgendada näiteks sõnade tõsine, rõõmus või tark esmatähendust. Mallis TEMPERATUUR-PSÜHH vaheldub temperatuuriomadus psühholoogilise omadusega. Temperatuuriadjektiivide valimis esines mall kahesuunaliselt, st sõnadel, mille esmatähendus väljendas temperatuuri, oli ka tähendus, mis väljendas inimpsüühikaga seotud omadust, ning sõnadel, mille esmatähendus oli psühholoogiline, esines tähendus, mis iseloomustas temperatuuri. Kahepoolselt läbipõimunud semantika viitab tugevale sidemele nende kognitiivsete valdkondade vahel.

Esmatähendusega temperatuurisõnadest kandsid malli TEMPERATUUR-PSÜHH kõik temperatuuri põhisõnad ( $k \ddot{u l m}$, soe, kuum, jahe), sealjuures viitasid sooja ja kuuma psühholoogilised tähendused pigem positiivsetele omadustele ning külma ja jaheda omad pigem negatiivsetele. Soojaga väljendatakse sõbralikkust, südamlikkust (soe inimene, soe naeratus, soe vastuvõtt), kuumaga kirglikkust (kuumad tunded, kuumad suudlused, kuum paar), külmaga ebasõbralikkust, tundetust või ükskõiksust (külm suhtumine, külm pilk, külm süda) ja jahedaga samuti ükskõiksust, mittesüdamlikkust (jahe vastuvõtt, jahedad suhted, jahe viisakus).

TEMPERATUUR-PSÜHH on valimi kõige levinum polüseemiamall, mis kehtib enamike polüseemsete temperatuuriadjektiivide juures (palav, tuline, leige, jäine jt). Ka sõnadel, mille puhul EKS-is polnud psühholoogilist tähendust esile toodud, sai korpuse abil tuvastada kollokatsioone, mis kinnitasid vastavat kasutust. Näiteks võivad psühholoogilisele omadusele viidata adjektiivid tulikuum (nt tulikuum armuöö) ja jahedavõitu (nt jahedavõitu suhted) analoogiliselt kuuma ja jahedaga, ent sõnastikus võib sõna enda sagedus suuresti mõjutada tähenduste esitust. Harvemal sõnal ei pruugi kogu võimalik tähendusstruktuur olla sama põhjalikult esitatud kui sageda sõna juures.

Psühholoogilise esmatähendusega sõnu, millel esines ka temperatuuritähendus, oli valimis mitmeid. Järjekorras PSÜHH-TEMPERATUUR esinesid tähendused 
nt sõnadel kõhe, kale, mahe, leebe ja karm. Ka siin võis täheldada positiivsete psühholoogiliste omaduste vaheldumist sooja temperatuuriga (mahe, leebe) ja negatiivsete omaduste vaheldumist külmaga ( $k o \tilde{h} e$, kale, $\mathrm{karm}$ ). Eesti emotsioonisõnade uurija Ene Vainik (2016: 285) toob välja, et seda erinevates keeltes ja kultuurides ilmnevat püsiseost kiindumuse ja soojuse vahel on seletatud universaalse nn primaarmetafoorina ehk seosena, mis kujuneb meil kõigil imikueas kehalisest süles hoituse kogemusest.

Seost soojuse ja sõbralikkuse vahel kinnitavad ka käitumisteaduste eksperimendid. Kaks päevikukatset (Fetterman jt 2018) näitasid, et päevadel, kui katses osalejad tundsid ennast füüsiliselt soojemalt, tajusid nad endid olevat ka inimestevahelistes suhetes südamlikumad ja vastuvõtlikumad, sõltumata õuetemperatuurist. Tulemused lubavad eeldada, et sõbralikkus võib varieeruda vastavalt sellele, kas inimene tunneb, et tal on konkreetsel päeval soe või külm. Seega on süstemaatilisel mallil TEMPERATUUR-PSÜHH otsene kehalisest kogemusest lähtuv motivatsioon.

Siiski on temperatuurisõnade uurija Maria Koptjevskaja-Tamm (2015) pakkunud, et temperatuuriga seotud metafoorid ei pruugi olla universaalsed, vaid sõltuvad kultuurist ja keskkonnast. Aafrikas kõneldavas eve keeles seostatakse soojust ja kuumust sageli hoopis päikese põhjustatud valuga (Ameka 2015). Ka hiljutine värviuurimus (Jonauskaite jt 2019) näitas, et kuigi kollase värviga seotud emotsiooniks peetakse peamiselt rõõmu ja rahulolu (kuna kollane tähistab päikesepaistet ja meeldivat ilma), ei kehtinud see näiteks Sahara kõrbes elavate rahvaste seas, kellel kollane värv seondus pigem kuuma liiva ning kõrvetava päikesega. Uurimusest selgus, et kollase värvi seos rõõmsa emotsiooniga erines piirkonniti suurel määral. Näiteks Soomes, kus päikselisi ilmu on vähem, seostas kollast rõõmuga lausa 87,7\% vastanutest, kuid Egiptuses ainult 5,7\%.

Eelnevast lähtuvalt kerkis küsimus: kas soojus seostub enim positiivsusega ja külm enim negatiivsete emotsioonidega just piirkondades, kus soe ilm on pigem harv nähtus? Sellele küsimusele ammendavalt vastamine vajaks keeltevahelist võrdlust, kuid et selgitada eesti temperatuuri põhisõnade lähedust positiivsust või negatiivsust väljendavate adjektiividega, võrdlen põhisõnade seoseid Sketch Engine'i tesauruse funktsiooni abil (tabel 1). Tesaurus koondab sõnu, mis esinevad sarnastes kontekstides, ja võimaldab vaadelda, millistel sõnadel on temperatuuri põhisõnadega enim ühiseid kollokatsioone. Seose tugevuse näit arvutatakse ühiste kollokatsioonide osakaalu põhjal. Tabelis on esitatud põhisõnade tugevaimad seosed.

Põhisõnade tesaurusepildis esineb enim seoseid positiivset tähendust kandvate adjektiividega sõnal soe. Peale teiste temperatuurisõnade esilduvad sooja juures sõnad mõnus, ilus, pehme, kuiv, kena, rahulik, meeldiv ja puhas, ühtegi seost negatiivsete omadustega ei esine. Külma all seevastu tulevad lisaks teistele temperatuurisõnadele esile adjektiivid pime, niiske, igav, pehme, märg, vaikne ja kole, mille hulgas on kaks negatiivset hinnangut väljendavat sõna, igav ja kole. Jaheda puhul tulevad esile neutraalsemad kliimasõnad ja tesauruseseoste hulgas puuduvad hinnangulised omadussõnad. Huvitav on aga, et põhisõna kuum, mis võiks viidata ka juba liigsele soojusele ja jagada kollokatsioone ebameeldivamate omadustega, seostub samuti ainult positiivsega. 
Tabel 1. Eesti temperatuuri põhisõnade distributiivne tesaurus ENC17 põhjal

\begin{tabular}{|c|c|c|c|}
\hline külm & soe & kuum & jahe \\
\hline jahe 0,287 & külm 0,257 & külm 0,233 & külm 0,287 \\
\hline soe 0,257 & jahe 0,234 & soe 0,224 & niiske 0,250 \\
\hline kuum 0,233 & mõnus 0,230 & jahe 0,221 & soe 0,234 \\
\hline kuiv 0,229 & kuum 0,224 & kuiv 0,197 & vihmane 0,229 \\
\hline pime 0,214 & ilus 0,222 & palav 0,197 & palav 0,223 \\
\hline niiske 0,198 & pehme 0,219 & magus 0,194 & karge 0,222 \\
\hline igav 0,192 & kuiv 0,214 & tuline 0,192 & kuum 0,221 \\
\hline pehme 0,189 & kena 0,203 & mõnus 0,174 & tuuline 0,218 \\
\hline märg 0,186 & rahulik 0,199 & niiske 0,174 & kuiv 0,215 \\
\hline vaikne 0,185 & meeldiv 0,191 & pehme 0,172 & hämar 0,212 \\
\hline kole 0,184 & puhas 0,189 & kena 0,168 & pime 0,206 \\
\hline
\end{tabular}

Kuigi ka eesti keeles võib seostada kuumust negatiivsete emotsioonidega (näiteks metafoorist VIHA ON KUUM VEDELIK on kirjutanud Ene Vainik (2017: 29)), sellele siinses materjalis viiteid ei esine. Kuuma seoste alt leiab sõnad magus, mõnus ja kena, mis tundub hoopis viitavat eestlaste soojalembusele ja annab tuge oletusele, et külma kliimaga piirkonnas seostub soojus positiivsete emotsioonidega eriti tugevalt.

\subsection{TEMPERATUUR-NÄHTUS_FÜÜS}

Teiseks sagedaim polüseemiamall temperatuuriadjektiivide valimis oli TEMPERATUUR-NÄHTUS_FÜÜS, kus adjektiivne temperatuuritähendus vaheldub substantiivse tähendusega, mis tähistab vastavat füüsikalist nähtust (nt soe ilm / sooja oli 20 kraadi). Adjektiivset ja substantiivset tähendust võiks käsitleda ka eri sõnadele kuuluvaina, kuid kuna EKS-is on sellised vaheldused esitatud polüseemiana, määratlesin siinses uurimuses temperatuurisõnade substantiivset kasutust adjektiivi tähendusvaheldusena.

Nagu mallis TEMPERATUUR-PSÜHH, esinevad ka malli TEMPERATUUR-NÄHTUS_ FüÜs üksused valimi erinevatel sõnadel erinevas järjekorras ja seda nii korpuses kui EKS-is. Korpuspäringu abil saab võrrelda sama sõna adjektiivse ja substantiivse kasutuse sagedusi. Sõnaliigid on ühendkorpuses automaatselt morfoloogiliselt märgendatud, kuid väljundis leidub ka vigu. Sõnaliikide täpsema määramisega tegeleb praegu ka Eesti Keele Instituudi töörühm projekti "Eesti keele sõnaliikide kategooriad korpusanalüüsi valguses” raames (Paulsen jt 2019).

Valdaval enamikul valimi sõnadest on sageduse poolest esil adjektiivne kasutus (nt soe: adjektiivina 171 300; substantiivina 33 532), kuid esines ka sõnu, mille adjektiivne ja substantiivne kasutus on korpuses üsna võrdsed (nt toasoe: adjektiivina 2 723; substantiivina 2 806) ja sõnu, mille puhul on tugevalt esil substantiivne kasutus (nt päevasoe: adjektiivina 30; substantiivina 435). Üldiselt langes EKS-i tähenduste järjekord kokku korpussagedusega, nt sõna päikesesoe adjektiivne kasutussagedus korpuses on 116 ja substantiivne 100 (näide 3). 
(3) päikesesoe

1 omadussõna päikesest köetud, päikesepaistest soe. Päikesesoe majasein 2 nimisõna päikesest, päikesepaistest lähtuv soojus. Päikesesoe on välja meelitanud usside armee.

Korpuse ja leksikograafilise esituse vahel esines ka lahknevusi, nt sõnad kehasoe (korpuses adjektiivina 53, substantiivina 41) ja ihusoe (adjektiivina 38, substantiivina 25), mis on esitatud täissünonüümidena ja korpuse põhjal mõlemad sagedamini adjektiivsed, erinevad EKS-is üksuste esitamise järjekorra poolest. Kehasoojal on esimesena antud substantiivne tähendus ja ihusoojal adjektiivne tähendus.

Malli produktiivsust demonstreerib paremini korpus. Väiksema sagedusega sõnade juures võis olla sõnastikus esitatud üks malli osapooltest, kuid korpusest leidis nimisõnalise NÄHTUS_FüÜs kasutuse näiteid ka EKS-i ühetähenduslikele temperatuuriadjektiividele nagu tulipalav ja kõrbekuum (korpusenäide: Mõni ime, ise kuivaks ka sellises kõrbekuumas ära, kui jõgi oleks.) Kogu mall võiks olla EKS-is esitatud ka ühe tähenduse all (näide 4).

(4) õuekülm omadussõna nimisõna madal temperatuur väljas. Õuekülmast tuppa toodud jõulukuusk. Õuekülmad käed.

\subsection{Tajumallid}

Meeleelunditega seotud polüseemiamalle koorus temperatuurisõnade analüüsist neli: TEMPERATUUR-HÄÄL, TEMPERATUUR-VÄRVUS, TEMPERATUUR-PUUDUTUS ja TEMPERATUUR-MAITSE. Mallis TEMPERATUUR-HÄÄL vaheldub temperatuuriomadus häält või heli iseloomustava omadusega (soe supp - soe bariton). Mallis TEMPERATUUR-VÄRVUS vaheldub temperatuuriomadus värvust või valgust iseloomustava omadusega (külm jook - külm valgus). Mall TEMPERATUUR-PUUDUTUS kodeerib temperatuuritähenduse vaheldust tähendustega, mis väljendavad (temperatuuriga seondumatut) puudutamisel tekkivat aistingut (karm talv - karmi karvaga koer) ja mall TEMPERATUUR-MAITSE vaheldust temperatuuri ja maitset iseloomustavate tähenduste vahel (tuline radiaator - tuline kaste).

Meelte hierarhia (2) teooria pakub välja, et kui tajukogemuse kirjeldamiseks vajatakse sõnavara, siis saab alati laenata sõna vasakult, kõrgema kategooria poolt ja mitte kunagi paremalt, madalama kategooria poolt (Viberg 1983). Temperatuuriadjektiivide polüseemiamallide uurimine seda ei kinnita. Temperatuuri kui puudutusega seotud valdkonna sõnadel esines kasutust nii nägemise kui kuulmise valdkonnas ehk siis kõrgemates kategooriates. Esmatähendusega temperatuurisõnadel nagu külm ja soe esinesid nägemismeelega seotud teisesed tähendused ( külm värv, soojad toonid). Samuti esines esmatähendusega temperatuuriadjektiividel (nt soe, jäine) korpuse põhjal häält ja heli kirjeldavaid tähendusi (nt sooja kõlaga,jäine hääl).

Tajumallide leksikograafiline esitus varieerus, tajutähendused võisid olla eksplitsiitselt esile toodud ja teineteisest eraldatud, kuid kõik meeled võisid olla koondatud ka ühe tähenduse alla. Näiteks esineb sõnal pehme tähendus definitsiooniga "meeltele rahulikult mõjuv, mitte intensiivne, terav ega tugev" ja tähenduse 
alt leiab keelenäiteid erinevate tajuvaldkondade kohta (Naisel oli madal pehme hääl. Pehme valgus mahendab kontraste ..) Tajutähenduste näiteid võis korduvalt leida ka laiema psühholoogilise tähenduse alt, nt sõnal kalk esineb tähendus definitsiooniga "(inimese olemuse kohta:) ilma südamlikkuse ja soojuseta, tundetu või ükskõikne", mille juures on hääletähenduse näide: Kuulsin Peedu kalki häält.

Viiest meelest ei tulnud temperatuurisõnadel esile polüseemiamalli ainult haistmismeelega seotud tähendustega. Ainsana esinesid nii temperatuuri kui lõhnaga seotud näited sõnal vinge (vinge tuul, vinge suitsuhais), kuid teiste temperatuurisõnade juures lõhnale viitavaid keelenäiteid ei esildunud.

Malli TEMPERATUUR-VÄRVUS uurimisel võis märgata põhisõnade korpuspildis temperatuuriadjektiivide tendentsi esineda koos kindlate värvidega. Külmaga seondusid põhiliselt külmad värvid valge ja sinine (kollokatsioonides külm valge, külm sinine), jaheda juures esildus samuti sinine (jahe sinine), soojaga esildus kõige rohkem värve (soe valge, soe kollane, soe pruun, soe punane ja soe roheline) ning kuumaga seondus roosa värv (kuum roosa). Viimasel puhul on ilmselt tegu inglise keele tõlkelaenuga värvimääratlusest hot pink.

\subsection{TEMPERATUUR-KOOSNEMINE}

Semantiline tüüp кOOSNEMINE koondab millegi koostist, ehitust väljendavaid omadusi. Temperatuurisõnade valimis esildusid sellised tähendused näiteks sõnadel jäine ja krõbe. EKS-is on vastavaid tähendusi defineeritud järgmiselt: jäine - "jääst koosnev või jääga kaetud..”, krõbe - “(toidu kohta:) kuiva, krõbisedes mureneva pealispinna või koostisega..”. Mall TEMPERATUUR-KOOSNEMINE kodeerib temperatuuritähenduse vaheldumist millegi koostist, ehitust iseloomustava tähendusega (nt jäine külmus, jäine koorik; krõbe pakane, krõbe piparkook).

\section{5. КOHT-TEMPERATUUR}

Malli KOHT-TEMPERATUUR osad on esitatud teiste mallidega võrreldes vastupidises järjekorras, kohatähendused eespool ja temperatuuritähendused teisena. Semantiline tüüp конт koondab mingi koha või piirkonnaga seotud omadust väljendavaid sõnu ja konkreetse malli sõnade esmatähendus oli eranditult kohatähendus. Omadussõna, mis tähistab teatud geograafilisest piirkonnast pärinemist või sinna kuulumist, on hakanud tähistama ka vastava piirkonnaga seostatavaid kliimaolusid ja temperatuuri (nt arktilise korpusnäidetes конт: Üle neeme kulgeb tähtis arktiliste lindude rändetee, TEMPERATUUR: Nüüd lubab mingit arktilist külma koos lumetormiga kah veel.)

\subsection{TEMPERATUUR-LIIKUMINE}

Semantiline tüüp LIIKUMINE märgib liikumise ja tempoga seotud omadusi ja mall TEMPERATUUR-LIIKUMINE kodeerib vaheldumist temperatuuritähenduse ning tempotähenduse vahel. Valimis esines mall rohkem soojaga seotud sõnade juures, nt palavikuline (palavikuline nahk, palavikuline sagimine) ja palav (palav suvepäev, 
palav heitlus), mis langeb kokku primaarmetafooriga TEGEVUSE INTENSIIVSUS ON KUUMUS (Grady 1997: 290) ning on kehalisest kogemusest motiveeritud, kuna aktiivne liigutamine tekitab soojatunnet. Esines aga ka kiiret liikumist iseloomustav tähendus külmaga seotud sõna juures käre (käre talv, käre jõgi).

\subsection{TEMPERATUUR-VANUS}

Semantiline tüüp vANUS koondab kellegi või millegi ea, olemasolu ajaga seotud tähendusi. Mallis TEMPERATUUR-VANUS vaheldub temperatuuritähendus eaga seotud tähendusega, nt sõnas ahjusoe (ahjusoojad pirukad, ahjusoe raamat).

\subsection{Tulemused}

Uurimuses selgitatud polüseemiamallid on kokkuvõtlikult esitatud tabelis 2. Mallid on järjestatud vastavalt sõnade arvule, mis näitab, kui mitmel temperatuuriadjektiivil oli vastav polüseemiamall EKS-is eksplitsiitselt esitatud - seega malli leksikograafilist esindatust. Et osutada, millised temperatuurisõnad kirjeldatud malli kandsid, on toodud ka näiteid valimist. Korpusanalüüsis avaldusid mallid suurema hulga sõnade juures.

\section{Kokkuvõte}

Temperatuurisõnade analüüsi tulemusena tuli esile 10 polüseemiamalli. Kõige produktiivsem mall temperatuuriadjektiivide rühmas on TEMPERATUUR-PSÜHH ehk temperatuuri tähistava tähenduse vaheldumine psühholoogilist omadust tähistava tähendusega. Mall esines valimis kahesuunaliselt: sõnadel, mille esmatähendus osutas temperatuurile, oli ka psühholoogilise omaduse tähendus ning sõnadel, mille esmatähendus oli psühholoogiline, esines temperatuuri kirjeldav tähendus. Läbipõimunud tähendusstruktuurid viitavad tugevale sidemele nende kognitiivsete valdkondade vahel.

Malli TEMPERATUUR-PSÜHH analüüs näitas ka sooja seondumist positiivsete omadustega ja külma seondumist negatiivsete omadustega. Seost soojuse ja positiivsete tunnete vahel on kinnitatud eksperimentaalselt ja seletatud ka universaalse primaarmetafoorina, mis kujuneb meil kõigil imikueas kehalisest süles hoituse kogemusest. Seega on süstemaatilisel mallil TEMPERATUUR-PSÜHH otsene kehalisest kogemusest lähtuv motivatsioon.

Siiski on pakutud, et temperatuuriga seonduvad suhtumised keeles ei pruugi olla universaalsed, vaid sõltuvad ka keelekasutajate kultuurist ja keskkonnast. Eesti temperatuuri põhisõnade seondumist meeldiva või ebameeldivaga uurisin Sketch Engine’i tesauruse funktsiooni abil, mis võimaldas vaadelda korpusest ühiste kollokatsioonidega adjektiive. Ootuspäraselt ilmnesid külma puhul negatiivset hinnangut väljendavad adjektiivid ja sooja puhul positiivse tähendusega sõnad. Jaheda tugevamate tesauruseseoste hulgas hinnangulisi omadussõnu ei esinenud. Põhisõna kuum, mis võiks viidata juba liigsele soojusele ja omada ühiseid kollokatsioone 
Tabel 2. Temperatuuriadjektiivide polüseemiamallid

\begin{tabular}{|c|c|c|c|}
\hline Mall & $\begin{array}{c}\text { Sõnu } \\
\text { valimis }\end{array}$ & Näited & Malli kirjeldus \\
\hline TEMPERATUUR-PSÜHH & 24 & $\begin{array}{l}\text { külm, soe, jäine, } \\
\text { leige, kuum }\end{array}$ & $\begin{array}{l}\text { Temperatuuritähendus } \\
\text { vaheldub meeleolu, suhtumist } \\
\text { või iseloomu väljendava } \\
\text { omadusega }\end{array}$ \\
\hline TEMPERATUUR- NÄHTUS_FÜÜS & 14 & $\begin{array}{l}\text { vilu, toasoe, palav, } \\
\text { suvesoe }\end{array}$ & $\begin{array}{l}\text { Adjektiivne } \\
\text { temperatuuritähendus } \\
\text { vaheldub } \\
\text { substantiivitähendusega, mis } \\
\text { tähistab vastavat füüsikalist } \\
\text { nähtust }\end{array}$ \\
\hline TEMPERATUUR-KOOSNEMINE & 6 & $\begin{array}{l}\text { jäine, krõbe, } \\
\text { pehmeke, kalk }\end{array}$ & $\begin{array}{l}\text { Temperatuuritähendus } \\
\text { vaheldub millegi koostist, } \\
\text { ehitust väljendava } \\
\text { tähendusega }\end{array}$ \\
\hline TEMPERATUUR-HÄÄL & 6 & $\begin{array}{l}\text { käre, kalk, soe, } \\
\text { sume }\end{array}$ & $\begin{array}{l}\text { Temperatuuritähendus } \\
\text { vaheldub heli, häält } \\
\text { iseloomustava tähendusega }\end{array}$ \\
\hline TEMPERATUUR-VÄRVUS & 6 & $\begin{array}{l}\text { külm, soe, sume, } \\
\text { kalk, mahe }\end{array}$ & $\begin{array}{l}\text { Temperatuuritähendus } \\
\text { vaheldub värvust või valgust } \\
\text { iseloomustava tähendusega }\end{array}$ \\
\hline KOHT-TEMPERATUUR & 5 & $\begin{array}{l}\text { arktiline, } \\
\text { boreaalne, } \\
\text { atlantiline }\end{array}$ & $\begin{array}{l}\text { Adjektiiv, mis tähistab teatud } \\
\text { geograafilisest piirkonnast } \\
\text { pärinemist või sinna kuulumist, } \\
\text { on hakanud tähistama ka } \\
\text { vastava piirkonnaga seostuvaid } \\
\text { kliimaolusid ja temperatuuri }\end{array}$ \\
\hline TEMPERATUUR-LIIKUMINE & 5 & $\begin{array}{l}\text { palavikuline, palav, } \\
\text { käre }\end{array}$ & $\begin{array}{l}\text { Temperatuuritähendus } \\
\text { vaheldub liikumist ja tempot } \\
\text { iseloomustava tähendusega }\end{array}$ \\
\hline TEMPERATUUR-PUUDUTUS & 4 & pehme, karm & $\begin{array}{l}\text { Temperatuuritähendus } \\
\text { vaheldub tähendusega, mis } \\
\text { iseloomustab puudutamisel } \\
\text { tekkivat aistingut }\end{array}$ \\
\hline TEMPERATUUR-MAITSE & 3 & $\begin{array}{l}\text { tuline, mahe, } \\
\text { pehme }\end{array}$ & $\begin{array}{l}\text { Temperatuuritähendus } \\
\text { vaheldub maitset } \\
\text { iseloomustava tähendusega }\end{array}$ \\
\hline TEMPERATUUR-VANUS & 2 & ahjusoe, soe & $\begin{array}{l}\text { Temperatuuritähendus } \\
\text { vaheldub millegi või kellegi } \\
\text { iga või olemasolu aega } \\
\text { iseloomustava tähendusega }\end{array}$ \\
\hline
\end{tabular}


ka negatiivset hinnangut väljendavate omadussõnadega, seostub tugevamate tesaurusesuhete põhjal samuti ainult positiivsete sõnadega. Korpusanalüüs viitab eestlaste soojalembusele ja lubab oletada, et Eestis kui külma kliimaga piirkonnas on seos soojuse ja positiivsete emotsioonide vahel eriti tugev.

Teiseks sagedam polüseemiamall valimis on TEMPERATUUR-NÄHTUS_FÜÜS, milles temperatuuri tähistav adjektiivne tähendus vaheldub substantiivse tähendusega, mis tähistab vastavat füüsikalist nähtust. Selgitasin malli kandvate sõnade kasutuse korpussagedusi sõnaliigi alusel ja võrdlesin sagedusandmeid leksikograafilise esituse tähendusjärjekorraga. Enamasti langes EKS-i tähenduste järjekord korpussagedusega kokku, kuid esines ka lahknevusi.

Meeltega seotud polüseemiamalle koorus temperatuurisõnade analüüsist neli: TEMPERATUUR-HäÄL, TEMPERATUUR-VÄRVUS, TEMPERATUUR-PUUDUTUS ja TEMPERATUUR-MAITSE. Polüseemiamallide uurimine aga ei kinnitanud meelte hierarhia teooriat (Viberg 1983), mille kohaselt peaks meeltega seotud sõnavara areng järgima järjekorda NÄGEMINE $>$ KUULMINE $>$ PUUDUTAMINE $>$ LÕHN/MAITSE, kus tajukogemuse kirjeldamiseks saab sõna laenata vasakult, nö kõrgema kategooria poolt ja mitte paremalt, madalama kategooria poolt. Temperatuuri esmatähendusega sõnadel, mis ise kuuluvad kompimise/puudutamise valdkonda, esines regulaarseid tähendusvaheldusi nii nägemise kui kuulmise valdkonna tähendustega (soe valgus, jäine hääl). Niisiis võib väita, et kõrgema kategooria taju väljendamiseks on laenatud temperatuurivaldkonna sõnu.

Polüseemiamallide leksikograafiline esitus varieerus, mallis kodeeritavad tähendused võisid olla eksplitsiitselt esile toodud ja teineteisest eraldatud või esitatud koondtähendustena (nt hääle-, valguse- ja maitsetähendus üheskoos). Korpuses avaldus kõiki polüseemiamalle rikkalikumalt, kuid leksikograafilises töös võib saada otsustavaks sõna kasutussagedus, kusjuures väiksema sagedusega sõnade puhul ei pruugita võimaliku süstemaatiline vahelduse esiletoomist otstarbekaks pidada. Sellegipoolest leidus ka näiteid, kus mallis osutatud tähenduste korpussagedus oli arvestatav, ent sõnaraamatus esitamata. Näiteks on analoogiliselt jahedaga võime viidata psühholoogilisele omadusele ka adjektiivil jahedavõitu (jahedavõitu suhted).

Mallid aitavad keelematerjali teadlikumalt organiseerida ja lubavad leksikograafil heita sama semantilise rühma sõnadele laiema, süsteemsema pilgu. Mallide järjepidev esitus sõnaraamatus või andmebaasis ei pruugi olla omaette eesmärk, kuid kuna tähenduste esitamist mõjutavad mitmed tegurid (sihtrühma vajadused, sõna sagedus, tähenduse sagedus jne), aitab mallide tundmine vältida juhuslikumat tähenduse väljajättu. Mudel võiks hõlmata ka sõna polüseemiapotentsiaali, sõnaraamat aga kui konkreetse kasutuse näitaja ei peagi näitama kõiki võimalusi. Sagedate polüseemsete sõnade korpusanalüüsil on leksikograafi ees korraga väga palju informatsiooni ja tähenduste jagunemist võib olla keeruline hoomata. Seega kindlustab mallidega arvestamine sõnaraamatutöös, et tähenduse kaasamine või kõrvalejätmine on teadlik otsus. 


\section{Viidatud kirjandus}

Alonso, Héctor Martınez; Pedersen, Bolette Sandford; Bel, Núria 2013. Annotation of regular polysemy and underspecification. - Proceedings of the 51st Annual Meeting of the Association for Computational Linguistics. Vol. 2: Short Papers. Sofia: Association for Computational Linguistics, 725-730.

ALFE $=$ Atlas Linguarum Fennicarum. 1. Itämerensuomalainen kielikartasto. Läänemeresoome keeleatlas. Ostseefinnischer Sprachatlas. Лингвистический атлас прибалтийско-финских языков. Päätoim. Tuomo Tuomi. 1. osan vast. toim. Seppo Suhonen. Kartat: Anneli Hänninen; saksankielinen käännös: Klaas Ph. Ruppel, venäjänkielinen käännös: Vladimir Rjagojev, Nina Zaitseva, vironkielinen käännös: Helmi Neetar. Toimitus: Anneli Hänninen, Raimo Jussila, Lilja Kirppu, Arvo Laanest, Heikki Leskinen, Helmi Neetar, Vilja Oja, Vladimir Rjagojev, Ulla Vanhatalo, Tiit-Rein Viitso, Nina Zaitseva. Suomalaisen Kirjallisuuden Seuran toimituksia 800; Kotimaisten kielten tutkimuskeskuksen julkaisuja 118. Helsinki: Suomalaisen Kirjallisuuden Seura, Kotimaisten kielten tutkimuskeskus, 2004.

Ameka, Felix K. 2015. "Hard sun, hot weather, skin pain": The cultural semantics of temperature expressions in Ewe and Likpe (West Africa). - Maria Koptjevskaja-Tamm (Ed.), The Linguistics of Temperature. Typological Studies in Language 107. Amsterdam: John Benjamins, 43-72. https://doi.org/10.1075/tsl.107.02ame

Bhat, D. N. Shankara 1994. The Adjectival Category: Criteria for Differentiation and Identification. Studies in Language Companion Series 24. Amsterdam/Philadelphia: John Benjamins Publishing Company. https://doi.org/10.1075/slcs.24

Fellbaum, C. (Ed.) 1998. WordNet: An Electronic Lexical Database. Cambridge: MIT Press. https://doi.org/10.7551/mitpress/7287.001.0001

Fetterman, Adam K.; Wilkowski, Benjamin M.; Robinson, Michael D. 2018. On feeling warm and being warm: Daily perceptions of physical warmth fluctuate with interpersonal warmth. - Social Psychological and Personality Science, 9 (5), 560-567. https://doi. org/10.1177/1948550617712032

Grady, Joseph 1997. Foundations of Meaning: Primary Metaphors and Primary Scenes. PhD Thesis. Berkeley: University of California.

Jonauskaite, Domicele; et al.; Mohr, Christine 2019. The sun is no fun without rain: Physical environments affect how we feel about yellow across 55 countries. - Journal of Environmental Psychology, 66. https://doi.org/10.1016/j.jenvp.2019.101350

Juvonen, Päivi; Nikunlassi, Ahti 2015. Temperature adjectives in Finnish. - Maria Koptjevskaja-Tamm (Ed.), The Linguistics of Temperature. Typological Studies in Language 107. Amsterdam: John Benjamins, 491-536. https://doi.org/10.1075/tsl.107.16juv

Jürviste, Madis; Kallas, Jelena; Langemets, Margit; Tuulik, Maria; Viks, Ülle 2011. Extending the functions of the EELex dictionary writing system using the example of the Basic Estonian Dictionary. - Iztok Kosem, Karmen Kosem (Eds.), Electronic Lexicography in the 21st Century. New Applications for New Users: Proceedings of eLex 2011, Bled, 10-12 November. Ljubljana: Trojina, Institute for Applied Slovenian Studies, 106-112.

Kallas, Jelena; Tuulik, Maria; Jürviste, Madis 2012. Leksikograafilise tarkvara Sketch Engine eesti keele moodul ['Estonian language module of lexicographic software Sketch Engine']. - ESUKA/JEFUL, 3-2, 57-77. https://doi.org/10.12697/jeful.2012.3.2.03

Kilgarriff, Adam; Kovář, Vojtěch; Krek, Simon; Srdanovič, Irena; Tiberius, Carole 2010. A quantitative evaluation of word sketches. - Anne Dykstra, Tanneke Schoonheim (Eds.), Proceedings of the 14th EURALEX International Congress. Leeuwarden: Fryske Akademy, 372-379.

Koppel, Kristina; Tavast, Arvi; Langemets, Margit; Kallas, Jelena 2019. Aggregating dictionaries into the language portal Sõnaveeb: Issues with and without solutions. Iztok Kosem, Simon Krek (Eds.), Proceedings of eLex 2019 Conference: Electronic 
Lexicography in the 21st century: Smart Lexicography. Sintra: Lexical Computing, 434-452.

Koptjevskaja-Tamm, Maria 2015. Introducing “The Linguistics of Temperature”. - Maria Koptjevskaja-Tamm (Ed.), The Linguistics of Temperature. Typological Studies in Language 107. Amsterdam: John Benjamins, 1-40. https://doi.org/10.1075/tsl.107.01kop

Langemets, Margit 2010. Nimisõna süstemaatiline polüseemia eesti keeles ja selle esitus keelevaras ['Systematic Polysemy of Nouns and its Lexicographic Treatment in Estonian Language Resources']. Tallinn: Eesti Keele Sihtasutus.

Langemets, Margit; Uibo, Udo; Tiits, Mai; Valdre, Tiia; Voll, Piret 2018. Eesti keel uues kuues: Eesti keele sõnaraamat 2018 ['Estonian lexis revisited: The Dictionary of Estonian 2018']. - Keel ja Kirjandus, 12, 942-958.

Langemets, Margit; Uibo, Udo; Tiits, Mai; Valdre, Tiia; Voll, Piret 2019. “Eesti keele sõnaraamatu” stiiliraamat ['Stylebook for the Dictionary of Estonian']. Käsikiri Eesti Keele Instituudis.

Martelli, Federico; Navigli, Roberto; Spadoni, Paolo; Stilo, Giovanni; Velardi, Paola 2019. Lexical analytics for NLP: Sense clustering. https://elex.is/wp-content/uploads/2019/o8/ ELEXIS_D3_1_Lexical_semantic_analytics_for_NLP_sense_clustering_Final.pdf (1.10.2009).

McCarthy, Diana; Kilgarriff, Adam; Jakubíček, Miloš; Reddy, Siva 2015. Semantic word sketches. - Andrew Hardie, Federica Formato (Eds.), Corpus Linguistics 2015: Abstract Book. Lancaster: UCREL, 231-233.

Paulsen, Geda; Vainik, Ene; Tuulik, Maria; Lohk, Ahti 2019. The lexicographer's voice: Word classes in the digital era. - Iztok Kosem, Simon Krek (Eds.), Proceedings of eLex 2019 Conference: Electronic Lexicography in the 21st century: Smart Lexicography. Sintra: Lexical Computing, 319-337.

Sutrop, Urmas 2002. The Vocabulary of Sense Perception in Estonian: Structure and History. Frankfurt am Main: Peter Lang.

Sutrop, Urmas 2004. Temperatuurisõnad ja skaalad ['Temperature terms and scales']. Emakeele Seltsi aastaraamat, 50, 111-128.

Tuulik, Maria 2014. Adjektiivide polüseemia korpuses ja sõnaraamatus ['Adjectival polysemy in corpora and dictionaries']. - Eesti Rakenduslingvistika Ühingu aastaraamat, 10, 307-317. https://doi.org/10.5128/ERYa10.19

Tuulik, Maria; Langemets, Margit 2016. Systematic polysemy of Estonian colour adjectives. - Tinatin Margalitadze, George Meladze (Eds.), Proceedings of the XVII EURALEX International Congress: Lexicography and Linguistic Diversity. Thbilisi: Ivane Javakhishvili Tbilisi University Press, 702-708.

Tavast, Arvi; Langemets, Margit; Kallas, Jelena; Koppel, Kristina 2018. Unified data modelling for presenting lexical data: The case of EKILEX. - Jaka Čibej, Vojko Gorjanc, Iztok Kosem, Simon Krek (Eds.), Proceedings of the XVIII EURALEX International Congress: Lexicography in Global Contexts, Ljubljana, 17-21 July. Ljubljana: Ljubljana University Press, Faculty of Arts, 749-761.

Uusküla, Mari; Sutrop, Urmas 2011. Värvinimede raamat ['A Book of Colour Termes']. Töid antropoloogilise ja etnolingvistika vallast 5. Tallinn: Eesti Keele Sihtasutus.

Vainik, Ene 2016. Eesti tunded: Sõnaportreed ['Estonians' Feelings. The Words portraited']. Tallinn: Eesti Keele Sihtasutus.

Vainik, Ene 2017. Tunnetest, piltlikult ['About emotions, figuratively']. - Mäetagused, 69, 9-38. https://doi.org/10.7592/MT2017.69.vainik

Viberg, Åke 1983. The verbs of perception: A typological study. - Linguistics, 21 (1), 123-162. https://doi.org/10.1515/ling.1983.21.1.123 


\section{Kaudviide}

Apresjan, Jurij D. 1974. Regular polysemy. - Linguistics, 142, 5-32. https://doi.org/10.1515/ ling.1974.12.142.5

\section{Veebimaterjalid}

ENC17 = Kallas, Jelena; Koppel, Kristina 2018. Eesti keele ühendkorpus 2017 ['Estonian National Corpus 2017']. Center of Estonian Language Resources. https://doi. org/10.15155/3-00-0000-0000-0000-071E7L

EKS = Langemets, Margit; Tiits, Mai; Uibo, Udo; Valdre, Tiia; Voll, Piret (Toim.). Kuusik, Katrin; Kuusk, Külli; Langemets, Margit; Tiits, Mai; Uibo, Udo; Valdre, Tiia; Voll, Piret (Koost.). Viks, Ülle; Hein, Indrek; Tsepelina, Katrin (Koost.). Eesti keele sõnaraamat 2019 ['The Dictionary of Estonian 2019']. http://www.eki.ee/dict/eks (30.9.2019).

EstNLTK: Open source tools for Estonian natural language processing. https://estnltk.github. io/estnltk/1.4.1 (20.5.2020)

Sõnaveeb. https://sonaveeb.ee (28.9.2019). 


\title{
SYSTEMIC POLYSEMY PATTERNS OF ESTONIAN TEMPERATURE ADJECTIVES
}

\author{
Maria Tuulik \\ Institute of the Estonian Language, University of Tartu
}

The article gives an overview of temperature adjectives in Estonian and ascertains the regularities of their semantic structure. Patterns of systematic polysemy of temperature adjectives are identified, for the purpose of providing a theoretical framework for lexicographical work. The corpus data used in the article originates from Estonian National Corpus 2017 (ENC17). For corpus analysis Sketch Engine's (Kigarriff et al. 2014) word sketch, distributive thesaurus, and word lists functions are used.

To find the patterns, semantic types were added to meanings and similarities were searched among meaning shifts. The tagging of adjective meanings is based on the semantic types developed to describe Estonian (polysemous) adjectives (Tuulik 2014) and the typology has been further developed according to the semantics of temperature words. The semantic types are planned to be added to the new database of the Institute of the Estonian Language, Ekilex (Koppel et al. 2019), in order to allow for more precise search by lexicographers and researchers.

As a result of the analysis of the temperature words, 10 polysemous patterns emerged. The article discusses the potential motivation and lexicographic presentation of the more frequent patterns. Consistent presentation of patterns in a dictionary or database may not be an end in itself, as the presentation of meanings is influenced by many factors (target users' needs, word frequency, meaning frequency, etc.), but taking patterns into account ensures that inclusion or exclusion of the meaning is a conscious decision.

Keywords: semantic types, polysemy, lexicography, lexicology, semantics, corpus linguistics, Estonian

Maria Tuulik (Eesti Keele Instituut, Tartu Ülikool) uurib adjektiivide semantikat, polüseemiat ja sõnaliigipiire leksikograafia vaatenurgast.

Roosikrantsi 6, 10119 Tallinn, Estonia

maria.tuulik@eki.ee 